\title{
Ki67 expression in triple negative breast cancer: Correlation of Ki67 expression with other prognostic factors in breast cancer in Indian patients
}

\author{
Khanna $\mathbf{M}^{1}$, Kaur $\mathrm{K}^{2}$, Manjari $\mathbf{M}^{3}$, Khanna $\mathrm{A}^{4}$ \\ ${ }^{1}$ Dr Menka Khanna, Associate Professor, Department of Pathology, ${ }^{2}$ Dr. Kiranjot Kaur, Junior Resident, Department of \\ Pathology, ${ }^{3}$ Dr. MriduManjari, Professor \& Head, Department of Pathology, ${ }^{4}$ Ashish Khanna, Associate Professor, \\ Department of Microbiology; all authors are affiliated with SGRDIMSAR, Amritsar, Punjab, India
}

Address for Correspondence: Dr Menka Khanna, Email id:mona74_khanna@yahoo.co.in

\begin{abstract}
Introduction: Triple negative breast cancer ( TNBC) cases are not sensitive to hormonal therapy and till date no specific targeted medication has been found for TNBC. The present study aims to know the expression of Ki67 in TNBC tissues and in non-TNBC tissues using immunohistochemistry and to do correlation analysis of ki 67 expression with other clinicopathological parameters. Material and Methods: The present study was conducted on 160 cases of breast cancer received as specimens from January to august 2016 in the Pathology Department, Sri Guru Ram Das institute of medical sciences, Amritsar. Histopathological typing and grading was done followed by immunohistochemistry for ER, PR, Her2neu and ki67. Results: Ki67-positive expression were identified in 86.6\% TNBC cases (including 14 cases of strong Ki67 expression). By contrast, among 130 cases of non-TNBC, 98 cases were Ki67-positive, accounting for 75.3\%,(only 2 cases showed strong positivity) indicating a significant difference compared with that in the TNBC group that Ki67 proliferation index was higher in the cases with size $>2 \mathrm{~cm}$ also cases with lymph node metastasis showed high Ki67 proliferation index. Conclusion: Ki-67 index is relatively higher in TNBC than in non-TNBC cases. Ki67 expression correlated with tumor size and lymph node metastasis in breast cancer in the present study. Thus the increased expression of Ki67 may predict the increased proliferation of breast cancer cells, increased invasiveness, faste $r$ rate of growth and the high incidence of lymph node metastasis.
\end{abstract}

Keywords: Triple negative, Breast cancer, ki 67, Porgnosis

\section{Introduction}

The most common malignancy in females is breast cancer. In last decade the mortality rate due to breast cancer has decreased significantly, owing to early diagnosis and effective therapies [1]. The advancement of molecular biology has led to new modified classification breast cancer into four subtypes according to the various molecular types.

Manuscript received: $25^{\text {th }}$ August 2016

Reviewed: $05^{\text {th }}$ September 2016

Author Corrected: $14^{\text {th }}$ September 2016

Accepted for Publication: $24^{\text {th }}$ September 2016
The St. Gallen International Expert Consensus 2011 defined the breast cancer subtypes on immunohistochemistry (IHC) as: Luminal A $\left(\mathrm{ER}^{+}\right.$and/or $\mathrm{PR}^{+}, \mathrm{Her}^{-}$and low Ki67 - <14\%), luminal $\mathrm{B}\left(\mathrm{ER}^{+}\right.$and/or $\mathrm{PR}^{+}, \mathrm{Her}^{+} ; \mathrm{ER}^{+}$and/or $\mathrm{PR}^{+}, \mathrm{Her} 2^{-}$, high Ki67 - > 14\%), Her2-positive $\left(\mathrm{ER}^{-}, \mathrm{PR}^{-}\right.$and Her2 ${ }^{+}$) and the triple-negative type $\left(\mathrm{ER}^{-}, \mathrm{PR}^{-}\right.$and Her2 $\left.{ }^{-}\right)$.[2] The use of Ki-67 index as proliferation marker has shown to be useful in subclassifying luminal tumors into a good prognosis luminal A subgroup and a subgroup with 
poor prognosis to be luminal B $[3,4]$. The molecular classification of breast cancer determines the basis for treatment and the prognostic evaluation [5]. Triple negative breast cancer (TNBC) are highly invasive, have poor prognosis and exhibits certain organ oriented metastasis Further investigations should define the prognostic relevance of $\mathrm{Ki}-67$ in TNBC.

TNBC cases are not sensitive to hormonal therapy and till date no specific targeted medication has been found for TNBC.[6,7,8,9,10,11]. Therefore, lots of studies are emerging which are especially focusing on these cancers. The current study aims to know the expression of Ki67 in TNBC tissues and in non-TNBC tissues using immunohistochemistry and to do correlation analysis of ki 67 expression with other clinicopathological parameters.

\section{Material and Methods}

The present study was conducted on 160 cases of breast cancer received as mastectomy or lumpectomy specimens from January to august 2016 in the Pathology Department, Sri Guru Ram Das institute of medical sciences, Amritsar. The clinical history of the patients was taken. The tissue was fixed formalin and paraffin embedded and was then stained for Haematoxylin and Eosin for histopathological typing and grading. The histopathological grading of the breast carcinoma was done as per the modified Bloom Richardson grading system [12]. IHC was performed by using antibodies against the estrogen receptors (ER), the progesterone receptors (PR) (Diagnostic Biosystem) and Her2neu, Ki67 (Biocare Medical). The antigen retrieval was done by using pressure cooker with $10 \mathrm{mmol}$ citrate buffer at $\mathrm{pH}$ 6. Tris buffer was used as the wash buffer and diaminobenzene tetrahydrochloride (DAB) was used as the chromogen.

The endogenous activity was blocked by using hydrogen peroxide. After protein blocking, the slides were incubated overnight with the available ER, PR, Her2neu and Ki67 primary antibodies and were conjugated with streptavidin Horse Radish Peroxidase (HRP). The slides were counterstained with hematoxylin and eosin. The positivity for ER and PR were determined when $\geq 1 \%$ cells showed nuclear positivity [13]. Her 2 neu was considered positive when atleast $10 \%$ cells show strong membranous positivity. Tissues were considered to be positive for Ki67 when the proportion of positively stained cells was $>5 \%$. (-, $\leq 5 \% ;+, 6-25 \% ;++, 26-50 \% ;+++,>50 \%)$.

\section{Results}

Out of 160 cases 130 were non- TNBC (ER PR and /or Her2 neu positive) and 30 cases were TNBC constituting $18.7 \%$ of all cases. In total 124 of the 160 cases of breast cancer tissues Ki67 positivity, was present in $77.5 \%$. In 30 cases of TNBC, 26 cases of Ki67-positive expression were identified (86.6\%), including 14 cases of strong Ki67 expression.

By contrast, in the tissue from the 130 cases of non-TNBC, 98 cases were Ki67-positive, accounting for $75.3 \%$,(only 2 cases showed strong positivity) indicating a significant difference compared with that in the TNBC group (Table1).

Table-1: Ki 67 expression in TNBC and non TNBC cases.

\begin{tabular}{|c|c|c|c|c|c|}
\hline & \multirow{2}{*}{$\begin{array}{c}\text { Ki-67 } \\
\text { negative }\end{array}$} & \multicolumn{4}{|c|}{ Ki-67 Positive } \\
\cline { 3 - 6 } & & + & ++ & +++ & total \\
\hline TNBC (30) & 4 & $\mathbf{3}$ & $\mathbf{9}$ & $\mathbf{1 4}$ & $\mathbf{2 6}$ \\
\hline Non-TNBC (130) & 32 & $\mathbf{8 0}$ & $\mathbf{1 6}$ & $\mathbf{2}$ & $\mathbf{9 8}$ \\
\hline
\end{tabular}


Research Article

Table-2: Correlation of expression of Ki67 with the clinicopathological factors in breast cancer tissues.

\begin{tabular}{|c|c|c|c|c|c|c|c|c|}
\hline & \multicolumn{3}{|c|}{ TNBC Ki 67 } & \multicolumn{3}{c|}{ Non TNBC Ki 67 } \\
\cline { 2 - 9 } & -ve & + & ++ & +++ & -ve & + & ++ & +++ \\
\hline $\begin{array}{c}\text { Lymph Nodes } \\
\mathrm{N}_{\mathrm{x}(\text { (metastatic) }}\end{array}$ & 1 & 1 & 5 & 13 & 16 & 51 & 14 & 2 \\
$\mathrm{~N}_{0}$ & 3 & 2 & 4 & 1 & 16 & 29 & 2 & 0 \\
\hline $\begin{array}{c}\text { Size of tumor } \\
\leq 2 \mathrm{~cm}\end{array}$ & 3 & 1 & 4 & 3 & 17 & 24 & 3 & 0 \\
$>2 \mathrm{~cm}$ & 1 & 2 & 5 & 11 & 15 & 56 & 13 & 2 \\
\hline
\end{tabular}

Correlating the Ki67 proliferation index with the various clinicopathologial parameters it was found that Ki67 proliferation index was higher in the cases with size $>2 \mathrm{~cm}$ also cases with lymph node metastasis showed high Ki67 proliferation index. (Table 2) The expression of Ki67 in breast cancer tissues was significantly correlated with the tumor size and the lymph node metastasis. $(\mathrm{P}<0.05$ for both $)($ table 2$)$

\section{Discussion}

Breast cancer exhibit a lot of diversity in clinical manifestation, pathology, prognosis and molecular biology. TNBC-defined by ER, PR and HER2 negativity - is a group of tumors with poor prognosis and lack of targeted agents, such as trastuzumab or tamoxifen.

TNBC is usually associated with poor prognosis because of its high invasiveness, an aggressive tumor biology and young onset of age [6,7,8,9,10,11,13]. They comprise 15-20\% of all breast cancers and [14]. In present study TNBC constituted $18.7 \%$ of all breast cancer cases.

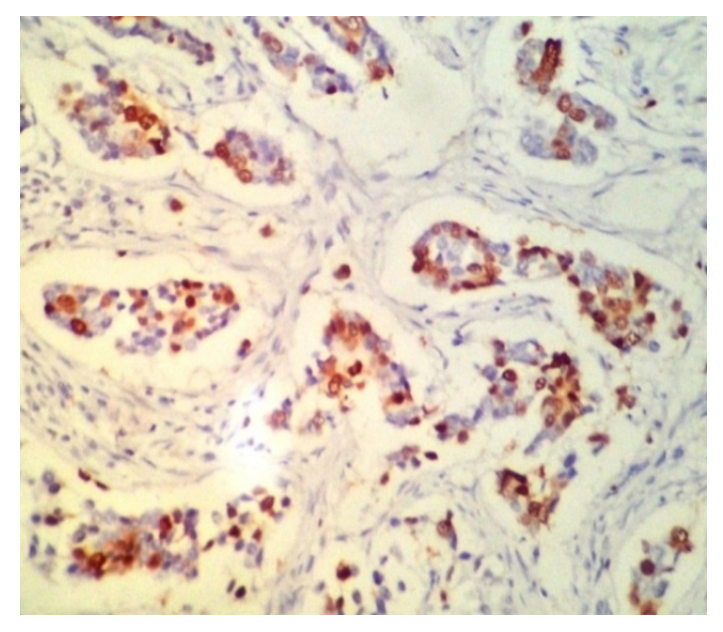

Figure 1: Immunohistochemical staining of Ki-67 (++) positivity (400x).

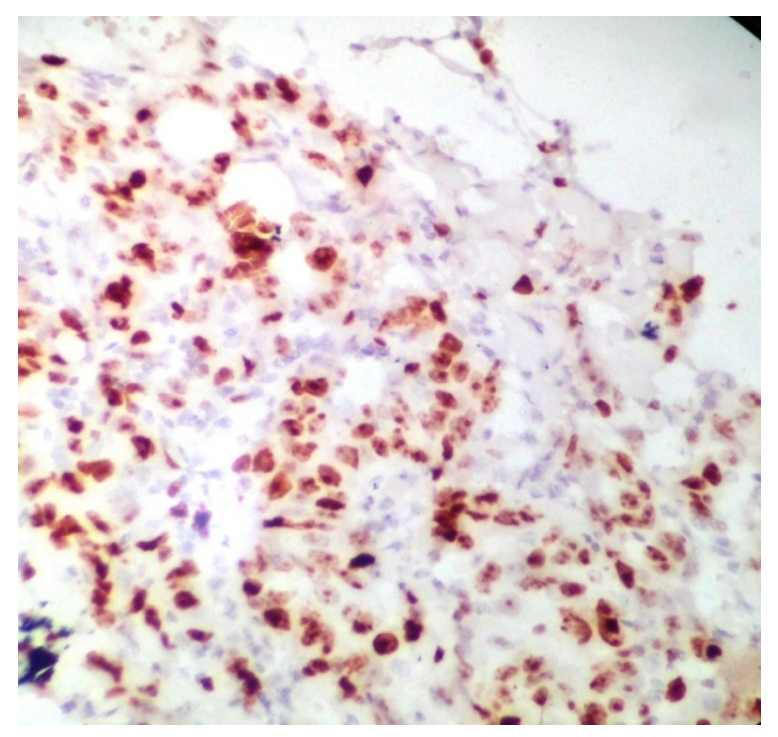

Figure 2: Immunohistochemical staining of Ki-67 $(+++)$ positivity showing high proliferative activity $(400 \times)$

Cellular proliferation is a major determinant of the biologic behavior of the tumors. Both Ki-67 and mitotic count are markers of cell proliferation. Although they are likely to be correlated with each other, due to variation in the mitotic rate subjected to fixation factors 
Research Article

and methodology, Ki-67 is considered a better proliferative prognostic marker. Ki-67 measurement by IHC is suitable for widespread use in clinical practice, and according to the "International Ki-67 in Breast Cancer Working Group", it is the current assay of choice [15].

In order to reduce inter-observer variability, it is advised that proliferative index should be expressed as the percentage of positively staining cells among a total number of invasive cells, preferably at least 1000 cells. Assessment of $\mathrm{Ki}-67$ on whole section slides is considered to be more reliable than on tissue microarray slides due to the heterogeneity of tumors [15].

In the current study, 160 patients with breast carcinoma were studied, and the overall positive rate of $\mathrm{Ki} 67$ expression was $77.5 \%$, which was comparable with the percentage (78\%) reported by other Indian authors [16]. The positive rate of Ki67 expression in TNBC was $86.6 \%$, including 14 cases with strong Ki67 expression. However, it was $75.3 \%$ in non-TNBC tissues, which was of lower when compared with that observed in the TNBC tissues. These results suggested that the increased expression of Ki67 may be an important factor for the poor prognosis of TNBC.

Because the Ki-67 index is relatively higher in TNBC than in non-TNBC it might play an important role in clinical practice in classifying TNBCs with different biological behaviour. Systemic chemotherapy represents the mainstay of treatment for TNBC [17].

Keam et al reported two new subgroups of TNBC according to $\mathrm{Ki}-67$ expression, with diverse prognosis and response rate to chemotherapy ' but poorer survival due to rapid recurrence within 3 years, and the authors suggested that the high proliferationpotential could explain the "triple negative paradox" [18].

TNBC with high Ki-67 expression were associated with a higher investigated,but only few studies have investigated the significance of Ki-67 in the TNBC subgroup [18,19,20]. In addition, Ki67 expression correlated with tumor size and lymph node metastasis in breast cancer in the present study. Thus the increased expression of Ki67 may predict the increased proliferation of breast cancer cells, increased invasiveness, faster rate of growth and the high incidence of lymph node metastasis.

Funding: Nil, Conflict of interest: None initiated, Permission from IRB: Yes

\section{References}

1. Shokouh TZ, Ezatollah A, Barand P. Interrelationships between Ki67, HER2/neu, p53, ER, and PR status and their associations with tumor grade and lymph node involvement in Breast Carcinoma subtypes. Medicine. 2015;94(32):e1359. doi: 10.1097/ MD.0000000000001359.

2. Goldhirsch A, Wood WC, Coates AS, Gelber RD, Thürlimann B, Senn HJ; Panel members. Strategies for subtypes--dealing with the diversity of breast cancer: highlights of the St. Gallen International Expert Consensus on the Primary Therapy of Early Breast Cancer 2011. Ann Oncol. 2011;22(8):1736-47. doi: 10. 1093/annonc/mdr304.

3. Prat A, Cheang MC, Martín M, Parker JS, Carrasco E, Caballero R, Tyldesley S, Gelmon K, Bernard PS, Nielsen TO, Perou CM. Prognostic significance of progesterone receptor-positive tumor cells within immunohistochemically defined luminal A breast cancer. J Clin Oncol. 2013;31(2):203-9. doi: 10.1200/ JCO.2012.43.4134.

4. Dawood S, Hu R, Homes MD, Collins LC, Schnitt SJ, Connolly J, Colditz GA, Tamimi RM. Defining breast cancer prognosis based on molecular phenotypes: results from a large cohort study. Breast Cancer Res Treat. 2011 ;126(1):185-92. doi: 10.1007/s10549-0101113-7.

5. Wang GS, Zhu H, Bi SJ. Pathological features and prognosis of different molecular subtypes of breast cancer. Mol Med Rep. 2012(4):779-82. doi: 10.3892 /mmr.2012.981. 
6. Lund MJ, Trivers KF, Porter PL, Coates RJ, LeylandJones B, Brawley OW, Flagg EW, O'Regan RM, Gabram SG, Eley JW. Race and triple negative threats to breast cancer survival: a population-based study in Atlanta, GA. Breast Cancer Res Treat. 2009; 113 (2):357-70. doi: 10.1007/s10549-008-9926-3.

7. Banerjee S, Reis-Filho JS, Ashley S. Basal-like breast carcinomas: clinical outcome and response to chemotherapy.. J Clin Pathol. 2006;59(7):729-35. doi: 10. 1007/s10147-008-0831-x

8. Carey LA, Dees EC, Sawyer L. The triple negative paradox: primary tumor chemosensitivity of breast cancer subtypes. Clin Cancer Res. 2007;13(8):2329-34. doi:10.1158/1078-0432.CCR-06-1109.

9. Bauer KR, Brown M, Cress RD, Parise CA, Caggiano V. Descriptive analysis of estrogen receptor (ER)-negative, progesterone receptor (PR)-negative, and HER2-negative invasive breast cancer, the socalled triple-negative phenotype: a population-based study from the California cancer Registry. Cancer. 2007; 109(9):1721-8.

10. Carey LA, Perou CM, Livasy CA. Race, breast cancer subtypes, and survival in the Carolina Breast Cancer Study. JAMA. 2006;295(21):2492-502. doi: 10. 1001/jama.295.21.2492.

11. Dent R, Trudeau M, Pritchard KI, Hanna WM, Kahn HK, Sawka CA, Lickley LA, Rawlinson E, Sun P, Narod SA. Triple-negative breast cancer: clinical features and patterns of recurrence. Clin Cancer Res. 2007; 13(15):4429-34.

12. Rosai J. The Breast. In: Rosai and Ackerman's Surgical Pathology. 10th Edition (Vol. 2). New York: Mosby (Elsevier);2012.p.1719-20.

13. Harvey JM, Clark GM, Osbome CK, Allred DC. Estrogen receptor status by immunohistochemistry is superior to the ligand-binding assay for predicting response to adjuvant endocrine therapy in breast cance. J Clin Oncol. 1999 ;17(5):1474-81 doi:10.1.1.452.3933
14. Bauer, K. R., Brown, M., Cress, R. D, Parise, C. A. \& Caggiano, V. Descriptive analysis of estrogen receptor (ER)-negative, progesterone receptor (PR)negative, and HER2-negative invasive breast cancer, the so-called triple-negative phenotype: a populationbased study from the California cancer Registry. Cancer. 2007;109(9):1721-8.doi:10.1002/cncr.22618.

15. M. Dowsett, T.O. Nielsen, R. A’Hern, J. Bartlett, R.C. Coombes, J. Cuzick, M. Ellis, N.L. Henry, J.C. Hugh, T. Lively, L. McShane, S. Paik, F. PenaultLlorca, L. Prudkin, M. Regan, J. Salter, C. Sotiriou, I.E. Smith, G. Viale, J.A. Zujewski, D.F. Hayes, Assessment of Ki-67 in breast cancer: recommendations from the International $\mathrm{Ki}-67$ in Breast Cancer working group. J Natl Cancer Inst. 2011 ;103(22):1656-64. doi: 10.1093/jnci/djr393.

16. Bhatavdekar JM, Patel DD, Shah NG, et al. Prognostic significance of immunohistochemically localized biomarkers in stage II and stage III breast cancer: a multivariate analysis. Ann Surg Oncol. 2000 ;7(4):305-11.

17. Kim T, Han W, Kim MK, Lee JW, Kim J Ahn SK, Lee HB, Moon HG, Lee KH, Kim TY, Han SW, Im SA, Park IA, Kim JY, Noh DY. Predictive Significance of p53, Ki-67, and Bcl-2 Expression for Pathologic Complete Response after Neoadjuvant Chemotherapy for Triple-Negative Breast Cancer. J Breast Cancer. 2015;18(1):16-21. doi: 10.4048/jbc.2015.18.1.16.

18. B. Keam, SA Im, KH Lee, SW Han, DY Oh, JH Kim, S.H. Lee, W Han, D Kim,TY Kim, I A Park, DY Noh, D S Heo, YJ Bang. Ki-67 can be used for further classification of triple negative breast cancer into two subtypes with different response and prognosis. Breast Cancer Res. 2011;13(2):R22. doi: 10.1186/bcr2834.

19. M. Miyashita, T. Ishida, K. Ishida, K. Tamaki, M. Amari, M. Watanabe, N. Ohuchi, H. Sasano, Histopathological subclassification of triple negative breast cancer using prognostic scoring system: five variables as candidates. Virchows Arch.2011; 458 (1):65-72. doi: 10.1007/s00428-010-1009-2. . 
20. MA Aleskandarany, AR Green, AA Benhasouna, F FBarros, K R Neal, J R Reis- Filho, IO Ellis, EA Rakha, Prognostic value of proliferation assay in the luminal, HER2 positive and triple negative biological classes of breast cancer. Breast Cancer Res. 2012; 14(1):62.doi: 10.1186/bcr3084.

\section{How to cite this article?}

Khanna M, Kaur K, Manjari M, Khanna A.mKi67 expression in triple negative breast cancer: Correlation of Ki67 expression with other prognostic factors in breast cancer in Indian patients. Trop J Path Micro 2016;2(2):76-81.doi: 10.17511/jopm.2016.i02.07 